解説

\title{
チムニーラダー型高マンガンケイ化物熱電材料の高性能化
}

\author{
宮㟝 讓*, 濱田 陽紀, 菊池 祐太, 林 慶 \\ 東北大学大学院工学研究科応用物理学専攻, $\bar{\top} 980-8579$ 仙台市青葉区荒巻字青葉 6-6-05.
}

\section{Enhanced Thermoelectric Properties of Chimney-ladder Type Higher Manganese Silicides}

\author{
Yuzuru MIYAZAKI*, Haruki HAMADA, Yuta KIKUCHI and Kei HAYASHI \\ Dept. Applied Physics, Tohoku University, 6-6-05 Aoba, Aramaki, Aoba-ku, Sendai 980-8579 Japan.
}

Received February 7, 2017; Revised March 3, 2017; Accepted March 4, 2017

\begin{abstract}
To further enhance thermoelectric (TE) properties of higher manganese silicides (HMSs), the dissipation of layered precipitates of the MnSi phase as well as the optimization of the hole carrier concentration are critical. We have systematically studied electronic structure of partially substituted solid solutions of $\left(\mathrm{Mn}_{1-x} M_{x}\right) \mathrm{Si}_{1.7}$ with $M=$ transition metals and prepared bulk samples of such solid solutions by spark plasma sintering. A 2 at $\%$ substitution of manganese with vanadium is found to dissipate the MnSi-precipitates effectively, results in a substantial increase in electrical conductivity from $3 \times 10^{4} \mathrm{~S} / \mathrm{m}$ to approximately $5 \times 10^{4} \mathrm{~S} / \mathrm{m}$ at $800 \mathrm{~K}$. The resulting TE power factor reaches $1.86 \mathrm{~mW} / \mathrm{K}^{2} \mathrm{~m}$ at $710 \mathrm{~K}, 30 \%$ higher than that of V-free samples.
\end{abstract}

\section{KEY WORDS}

higher manganese silicide, incommensurate composite crystal, valence electron counts, thermoelectric properties, chimney-ladder phase

\section{1 緒 言}

$\mathrm{Mn}$ と Si のモル比が 1:1.7 近傍の組成を持つ高マンガンケ イ化物（Higher Manganese Silicide, HMS）は, 1960-70 年代 よりロシアや我が国で精力的に研究されてきた $\mathrm{p}$ 型熱電材 料である ${ }^{1-3)}$. HMS は耐熱性・耐酸化性に富むことから, 空 気中でも室温以上 $1000 \mathrm{~K}$ 程度までの使用が可能である。ま た, 構成元素の地殼埋蔵量が豊富で毒性が低い長所も相まっ て, ガソリン自動車エンジンや工業炉の排熱（中温域：600$1000 \mathrm{~K}$ ）を利用する廉価な熱電発電材料として期待されてい る.これまで報告された中温域用熱電発電材料の殆どは, $\mathrm{Tl}, \mathrm{Te}, \mathrm{Pb}, \mathrm{Sb}, \mathrm{Se}$ 等の希少で有毒な元素から構成されて いるため, HMS 系熱電材料に対する期待は益々高まってき ている.しかしながら HMS の高性能化に向けては，克服す べき課題がある，通常，バルク合金材料は原料を溶融凝固さ せて合成する．しかし HMS は液相を経て合成すると，母相 内に異相晶出が生じて導電性や機械的強度が低下してしま う。また，HMS はホールキャリア濃度を最適值に制御でき

\footnotetext{
* Corresponding author, E-mail: miya@crystal.apph.tohoku.ac.jp
}

れば，出力因子は更に上昇しうることが理論的に指摘されて いる ${ }^{4,5)}$. 本稿では HMS におけるこれらの課題を解決すべく 行ってきた著者らの最近の研究を紹介する.

\section{HMS の構造上の特徵}

HMS として知られる化合物は 1 種類ではなく, 組成の類似 した少なくとも 4 相 : $\mathrm{Mn}_{4} \mathrm{Si}_{7}\left(\mathrm{MnSi}_{1.75}\right)^{6)}, \mathrm{Mn}_{11} \mathrm{Si}_{19}\left(\mathrm{MnSi}_{1.7272 .}\right)^{7)}$, $\mathrm{Mn}_{15} \mathrm{Si}_{26}\left(\mathrm{MnSi}_{1.733 . .}\right)^{8)}$ および $\mathrm{Mn}_{27} \mathrm{Si}_{47}\left(\mathrm{MnSi}_{1.7407 .}\right)^{9)}$ の存在が 報告されている，著者らは，組成も対称性も異なる化合物 として知られてきたこれらの HMS が，実はごく狭い単相組 成域を持つ「同一の化合物」であることを 2008 年に解明し た ${ }^{10)}$. Fig. 1 に HMS の結晶構造の一部を示す. HMS は Mn と $\mathrm{Si}$ の構造単位（副格子または部分構造と呼ばれる）が正 方晶の $a-b$ 軸を共有して, 異なる $c$ 軸周期 $\left(c_{\mathrm{Mn}} \sim 0.43 \mathrm{~nm}\right.$ と $\left.c_{\mathrm{Si}} \sim 0.25 \mathrm{~nm}\right)$ を持って積層した非整合複合結晶とよばれる物 質である. $c$ 軸長比を $\gamma=c_{\mathrm{Mn}} / c_{\mathrm{Si}}$ と定義すれば, HMS の構造 式は $\mathrm{MnSi}_{\gamma}$ と表記される. $\gamma$ は簡単な整数比では表現できず, 通常 1.72 1.75 近傍の無理数を取ることから 3 次元の単位胞 が定義できない. ごく稀に $4 c_{\mathrm{Mn}}=7 c_{\mathrm{Si}}$ 等の整数比で表され 


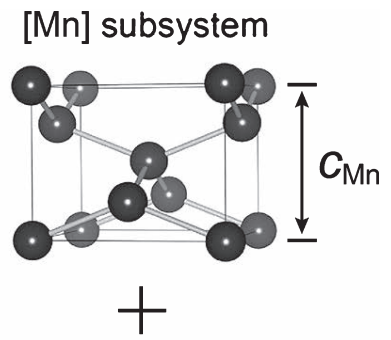

[Si] subsystem

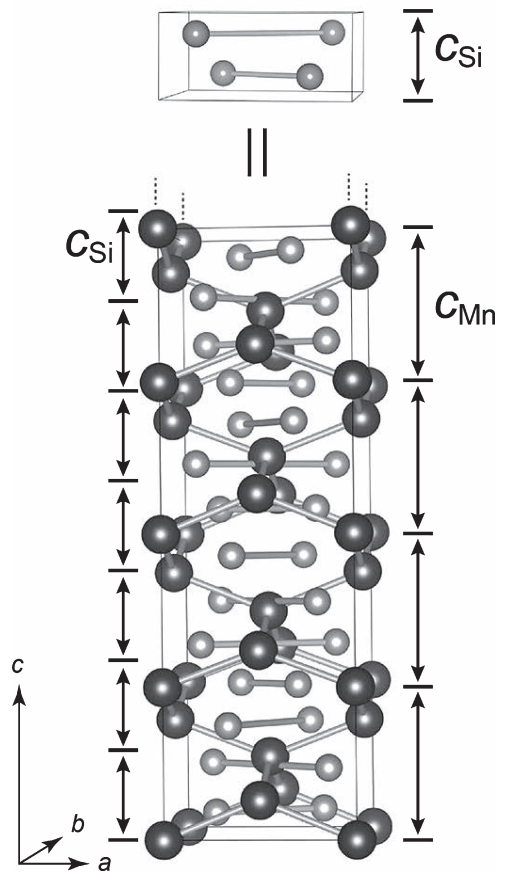

Fig. 1 Modulated crystal structure of HMS ( $\left.\mathrm{MnSi}_{y}\right)$, comprising two tetragonal sublattices of $[\mathrm{Mn}]$ and $[\mathrm{Si}]$ with different $c$-axis lengths.

る物質も存在するかも知れないが, 著者らのグループでは数 百もの異なる試料を合成した中で，一度も $\mathrm{Mn}_{4} \mathrm{Si}_{7}$ 組成の結 晶に出会ったことがない.

非整合結晶構造に由来して, 原子位置には変位変調（本来 いるべき位置から原子が共同的に変位すること）が生じてお $り$ ，特に $\mathrm{Si}$ 原子位置は螺旋階段を作るように $a-b$ 面内で大き く変位している. Mn 原子の作る四角柱状煙突 (chimney) の中を $\mathrm{Si}$ 原子の作る螺旋階段（ladder）が昇っていくように

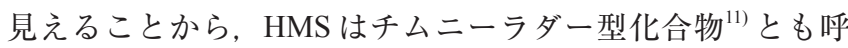
ばれている. HMSの変調構造については, 文献 に2)詳解さ れているので興味のある方はそちらも参照されたい.HMS に打けるキャリア伝導は主に Mn 3d 電子が担ゔ ${ }^{13)}$ ため, Si 原子の変位変調は格子熱伝導率を低減する上で効果的であ る. 多結晶試料の熱伝導率が室温において $3 \mathrm{~W} / \mathrm{Km}$ 程度と 低いのは，この $\mathrm{Si}$ 原子位置の変位変調によるところが大き い，高分解能電子顕微鏡（HREM）で格子像を撮ると, Si 原 子の配列が Mn 原子のそれとある角度を成して積層している $\left(c_{\mathrm{Mn}} \| c_{\mathrm{Si}}\right.$ でない) ドメインも存在する ${ }^{14,15)}$. この物質の X 線 回折パターンを測定すると, 粘土鉱物のように回折指数に よって半值幅が大きく異なるピークが出現する゙).つまり，
HMS は $1 つ の$ 化合物の中に規則的な配列をもつ Mn 原子と， 大きく乱れた配列をとる $\mathrm{Si}$ 原子が同居した，理想的な熱電 材料たりうる構造と見なすことができる.

\section{$3 \mathrm{MnSi}$ 相の縞状晶出とその抑制}

アーク溶解等，液相から HMS を合成する際には必ず母 相の HMS 中に MnSi（モノシリサイド）相の縞状晶出が生 じる. Fig. 2 (a), (b)にモノシリサイドの典型的な晶出形態と $\mathrm{Mn}-\mathrm{Si} 2$ 元系部分状態図 ${ }^{16)}$ を示す。ミクロ組織観察で報告さ れているモノシリサイド相の層厚は通常 1.6-3 $\mu \mathrm{m}$ 程度であり, $\mathrm{HMS}$ の $c$ 軸にほほ平行に数十 $\mu \mathrm{m}$ 程度の間隔で生成する ${ }^{17}$. この現象を, 状態図を参考にして理解しようとすると混乱す る. なぜなら, $\mathrm{Mn}: \mathrm{Si}=1: 1.75$ 近傍組成の融液を徐冷すると, 初晶として晶出するのはHMS ではなくモノシリサイド相で あるからである。液相とモノシリサイド相の 2 相共存域を経 て, 更に温度が降下すると HMS が包晶反応により生成する.
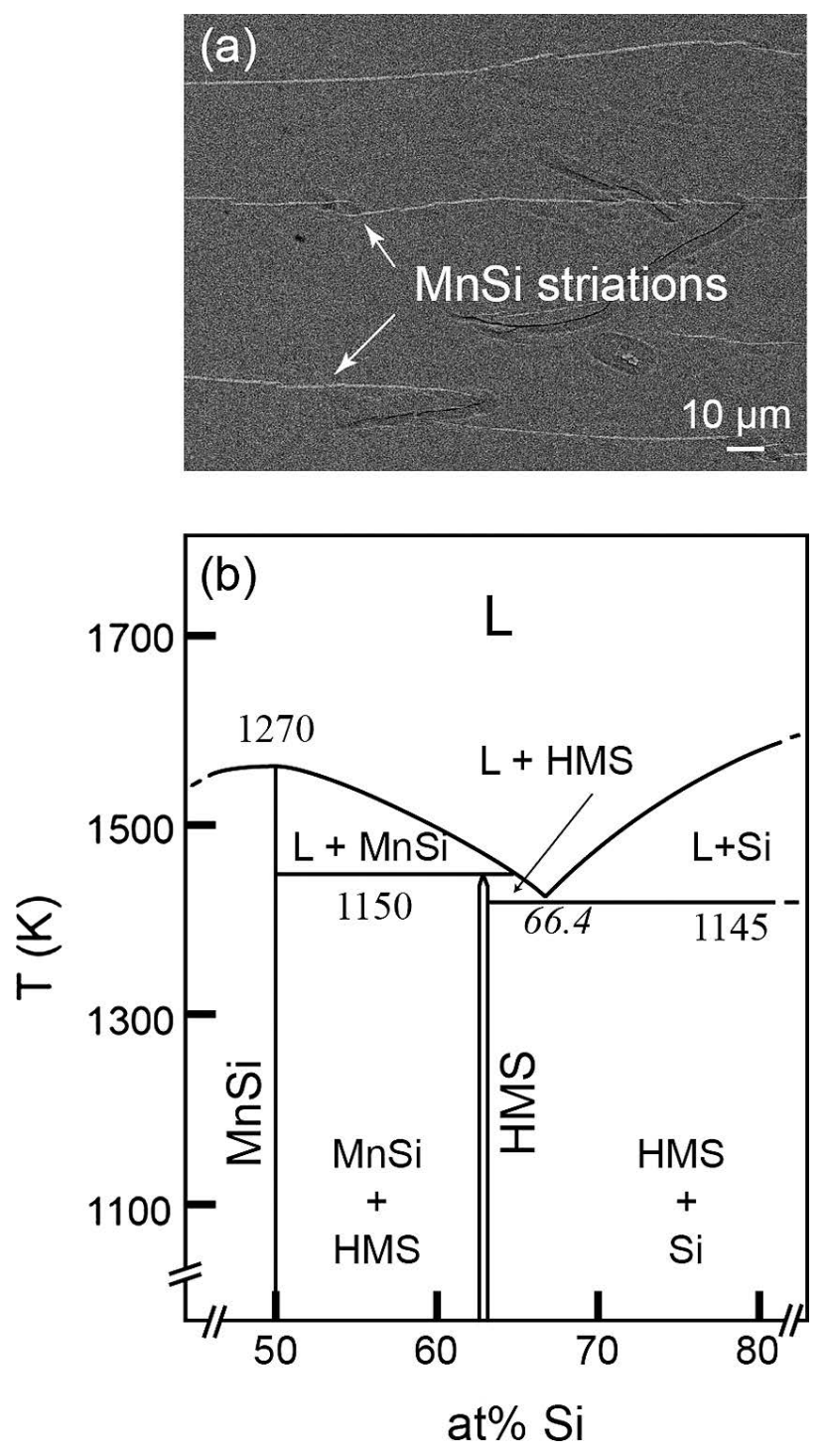

Fig. 2 (a) Typical layered precipitates of the MnSi phase observed in the matrix of HMS solidified from the liquidus phase. (b) A partial phase diagram of the Mn-Si binary system. 
つまり，HMS はモノシリサイドの縁に核生成・成長をする はずである。モノシリサイドは立方晶系であり，液相から初 晶として晶出する場合は，等方的に核成長して塊状組織を形 成すると考えられる。しかし実際は上述のように，先に晶出 するモノシリサイドが，後から生成するHMS の成長方向を 予め知っているかのように, HMS の $c$ 軸に平行にほぼ等間 隔の縞状，すなわち異方的に晶出する．状態図が間違ってい るのだろうか.

晶出した縞状モノシリサイド相は HMS と特定の結晶学的 方位を持たないため，両相の界面は原子配列が不連続にな り，導電性と機械的強度を低下させる。従って，モノシリサ イド相が生成しない条件を探索する必要がある。幸いなこと に, Si を Geで $0.5 \mathrm{at} \%$ 程度部分置換することにより，モノ シリサイドの縞が完全に消失するとの報告がなされた ${ }^{18)}$. 著 者らは, この現象は HMS の高性能化の鍵を握る極めて重要 なものと認識しており，種々の測定事実から縞状モノシリサ イド相の抑制に効果的な $\gamma$ の值が存在すると考えている. Si より原子半径の大きな $\mathrm{Ge} に よ る$ 部分置換は $c_{\mathrm{Si}}$ を伸長させ, $\gamma$ の值が無置換試料の 1.736 近傍から若干減少した結果，モ ノシリサイドの晶出抑制に効果的な $\gamma$ の值が実現したものと 推察される。

$\mathrm{Si}$ サイトへの Ge 置換固溶限は $1 \mathrm{at} \%$ 程度と低いので，著 者らは Mn サイトの他元素による部分置換により同様の現象 が見られないかを詳しく調べてきた。 その結果，バナジウム (V) で部分置換した試料がモノシリサイド相の縞状晶出を 抑制できることを見出した ${ }^{19)}$. $\left(\mathrm{Mn}_{1-x} \mathrm{~V}_{x}\right) \mathrm{Si}_{1.74}$ 組成の固溶相を SPS 合成したところ, $0 \leq x \leq 0.05$ の範囲で単相試料が得られ, また $x \geq 0.02$ の試料でモノシリサイド相が消失することが確 認された. $\mathrm{Mn}$ サイトを原子半径の大きな $\mathrm{V}$ （原子半径は $r_{\mathrm{Mn}}$ $=124 \mathrm{pm}$ および $r_{\mathrm{V}}=132 \mathrm{pm}$ である $\left.{ }^{20)}\right)$ で部分置換すること
により，当然 $c_{\mathrm{Mn}}$ 長は増大するが，同時に $c_{\mathrm{Si}}$ も大きく伸長し た.この結果, $x=0.02$ 試料の $\gamma$ は無置換試料の 1.736 に対し て 1.728 まで減少して抢り, $\mathrm{Ge}$ の Si サイトへの部分置換同 様， $\gamma$ はやや小さくっている，V同様に，Mnより大きな 原子半径を持つ $\mathrm{Cr}\left(r_{\mathrm{Cr}}=125 \mathrm{pm}\right)$ では, 部分置換により逆 に $\gamma$ は増加し，またモノシリサイド相の消失も認められない ことから, 1.72 近傍の $\gamma$ を持つ合金組成がモノシリサイド相 の抑制に効果があるものと判断できる.

\section{HMS の電子構造}

上述のように, 非整合複合結晶 HMS は 3 次元構造を定義 できないため，第一原理計算を行うことができない，従っ て，3次元の対称性で近似された整合結晶構造モデル（近似 構造モデル）を構築する必要がある。Fig. 3 に, $\mathrm{Mn}_{4} \mathrm{Si}_{7}$ の結 晶構造のを用いて計算された状態密度（DOS）のエネルギー 依存性（M=Mn）を示す．DOS の概形は，すでに同モデル を用いて行われた計算と良く一致している ${ }^{13)}$. 図には $\mathrm{Mn}_{4} \mathrm{Si}_{7}$ の Mn1 サイトを別の元素で置換した構造モデルを用いて計 算された DOSのエネルギー依存性も併せて示している。

$\mathrm{Mn}_{4} \mathrm{Si}_{7}$ には 5 つの $\mathrm{Mn}$ サイトがあり, $\mathrm{Mn} 1$ サイトを他元素 $M$ で置き換えた場合の化学式は $\left(\mathrm{Mn}_{0.875} M_{0.125}\right)_{4} \mathrm{Si}_{7}$ で表される.

まず無置換試料 $(M=\mathrm{Mn})$ についてみてみると, 特徴とし て約 $0.8 \mathrm{eV}$ の禁制帯を挟んで価電子帯上部と伝導帯下部にそ れぞれ大きな DOS が存在する．Fermi 準位（ $\left.E_{\mathrm{F}}\right)$ は，価電子 帯最上部にある。実際に合成される HMS の組成は $\mathrm{MnSi}_{173-174}$ 程度であるから、リジッドバンドモデルが適用できるという 仮定のもとでは， $E_{\mathrm{F}}$ は価電子带最上部を僅かに切る位置ま

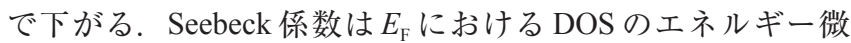
分に関連するので, HMS には高いSeebeck 係数 $S$ と高い導電 率 $\sigma$ の両立, すなわち高い出力因子 $P=S^{2} \sigma$ が期待される.

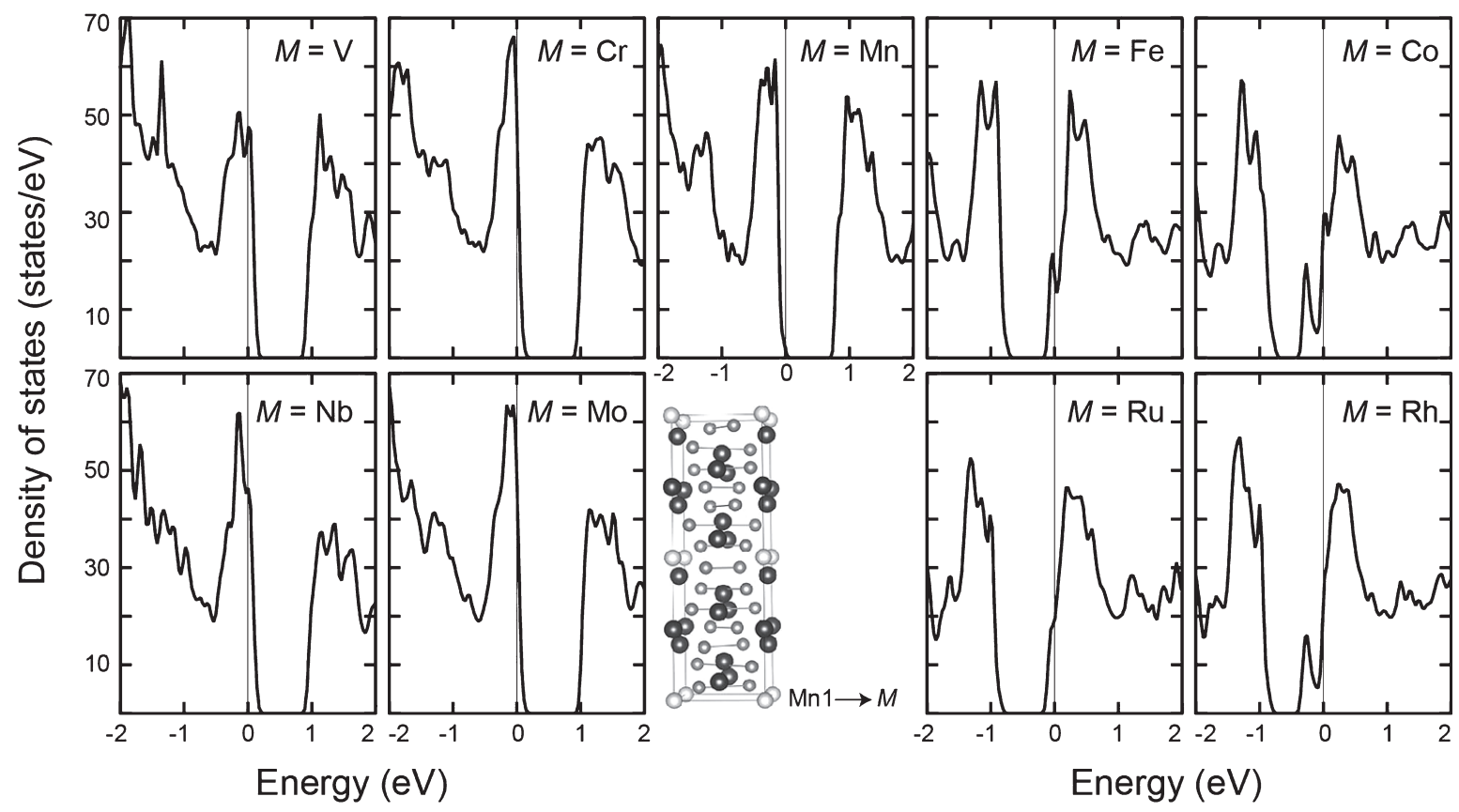

Fig. 3 Calculated density of states plotted against energy for the $\left(\mathrm{Mn}_{0.875} M_{0.125}\right)_{4} \mathrm{Si}_{7}(M=$ transition metals) solid solutions. 
次に Mnサイトを種々の元素 $M$ で部分置換した場合の DOS の変化をみてみる。実際の HMS 結晶では，特定のサイ 卜を他元素が規則的に占有することはあり得ないが, 元素置 換によるDOSの定性的変化を考察するにはこのモデルで充 分である. 周期表で Mnより左に位置する（価電子数の少な い) $\mathrm{Cr}$ や $\mathrm{Nb}$ で部分置換した場合， $E_{\mathrm{F}}$ が価電子带上端から幾 分低エネルギー側に入り达んでおり，ホールドープが進む （ホールキャリアが増加する）ことがうかがわれる，その結 果, 導電率は上昇するものの Seebeck 係数はやや減少すると 予想される。一方, 周期表でMnより右側に位置するCo や $\mathrm{Rh}$ で部分置換した場合， $E_{\mathrm{F}}$ は伝導帯の下部まで移動して $\mathrm{n}$ 型（負の Seebeck 係数）伝導を示すことが予想される． $E_{\mathrm{F}} に$ おけるDOSのエネルギー微分は $\mathrm{p}$ 型の場合と同様に急峻だ が符号が異なるので, $\mathrm{n}$ 型 HMS は負の高い Seebeck 係数が期 待できる。

電子構造計算からは，10\%程度の他元素置換による物性の 変化は概ね予想できるものの，僅かな組成の違いによる微妙 な電子構造の変化を表すためには, 別の手法が必要である. 著者らは構成元素の価電子数から計算される遷移金属 1 個あ たりの価電子数 VEC（Valence Electron Counts per number of transition metals）を用いて, 電子構造の変化を半定量的に評価 している. 置換元素 $M$ の価電子数を $V_{M}$ とすると, $\left(\mathrm{Mn}_{1-x} M_{x}\right) \mathrm{Si}_{\gamma}$ 固溶相における VEC は 7 $(1-x)+V_{M} x+4 \mathrm{~g}$ で表される. 例え ば $\mathrm{MnSi}_{1.736}$ の組成を持つ無置換試料の VEC は $7+4 \times 1.736=$ 13.944 であり，ホール（電子） ドープの場合はこの值より数 值が小さく（大きく）なる．またVEC > 14 となる組成では Seebeck 係数の符号が負となって $\mathrm{n}$ 型半導体に遷移すること が予想される ${ }^{21)}$

\section{5 ホールドープによる $\mathrm{p}$ 型熱電性能の向上}

$M=\mathrm{Cr}$ や Vの場合, 電子構造計算から導電性が向上し, 出力因子が増大する可能性が示唆された，著者らは理論予測 を実証するため，実際に多結晶試料の合成を行い熱電性能を 測定した。アーク溶解法により合成されたボタン状インゴッ 卜を微粉砕し，放電プラズマ焼結（SPS）により高密度化し た多結晶試料を合成した。SP 試料の焼結密度は理論密度に 対していずれも $93 \%$ 以上であった．Seebeck 係数と導電率は 同一試験片を用いて測定し，熱伝導率は同じロットのSPS 試料から別の部分を切り出して測定した. HMS は輸送特性 に異方性があるため, SPS 試料においても，切り出す方向に よって多少の異方性が現れると考えられる。このため本研究 では, SPS 時の加圧方向と垂直な面の物性を測定するように 試料を切り出して評価した.

Fig. 4 に V 置換多結晶試料の熱電性能の測定結果を示す. 図中, (a), (b) および (c) はそれぞれ Seebeck 係数 $S$, 導電率 $\sigma$ および出力因子 $P=S^{2} \sigma$ の温度変化を示している. 3 章で 述べたように，本合成条件の下では単相域は $0 \leq x \leq 0.05$ で あったので, $x$ を 0.05 まで 0.01 ずつ変化させた SPS 試料の 性能を測定した。まずFig. 4 (a)のデー夕を詳細にみると， いずれの試料においても $S$ は温度とともに増加し， $800 \mathrm{~K}$ 以

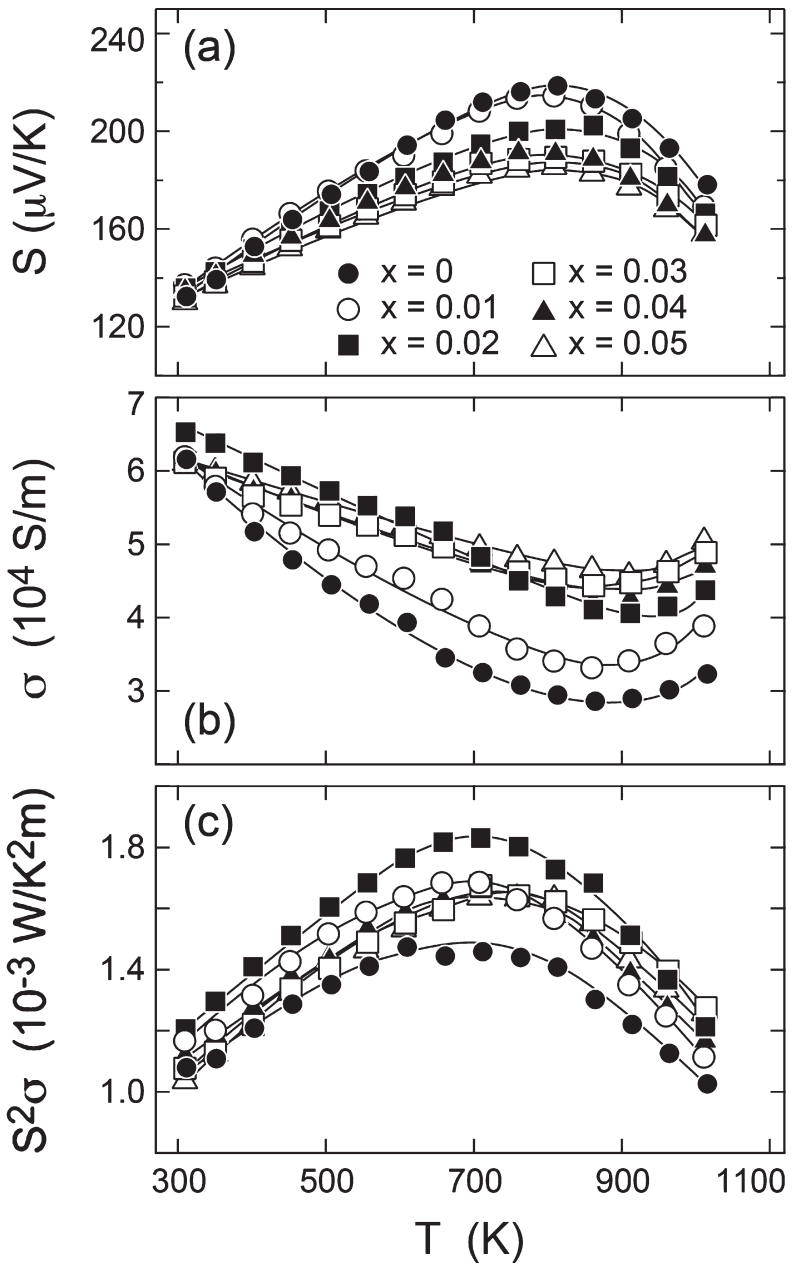

Fig. 4 Temperature dependence of the Seebeck coefficient $S$ (a), electrical conductivity $\sigma(\mathrm{b})$ and thermoelectric power factor $S^{2} \sigma$ (c) for the $\left(\mathrm{Mn}_{1-x} \mathrm{~V}_{x}\right) \mathrm{Si}_{\gamma}$ solid solution samples.

上の温度域では逆に減少した。無置換試料の $S$ は $813 \mathrm{~K}$ で最 大值 $220 \mu \mathrm{V} / \mathrm{K}$ を示し, $S$ の絶対值は $x$ の増加とともに単調に 減少する傾向が見られた。 $x=0.05$ の試料では $S$ の最大值は $186 \mu \mathrm{V} / \mathrm{K}(809 \mathrm{~K})$ にまで減少した。これらの変化は，V置 換によりホールキャリア密度が単調に増加することを示して いる. $S$ が最大となる温度 $T_{\mathrm{BD}}$ は，全ての測定試料で殆ど変 化は認められなかった。一般に $T_{\mathrm{BD}}$ は, 少数キャリアが伝導 に関与する両極性拡散の開始温度に対応しており， $E_{\mathrm{F}}$ から 伝導帯下端までのエネルギー (eV 単位) を 1000 倍した温度 ( $\mathrm{K}$ 単位) にほぼ一致する。

次に Fig. 4 (b) に示す $\sigma$ の温度変化をみる。 $\sigma$ は温度上昇と ともに金属的に減少し， $T_{\mathrm{BD}}$ よりやや高い温度で最小值を示 した後に増加に転じた，室温近傍における $\sigma$ の值はいずれの 試料も 6-7 $\times 10^{4} \mathrm{~S} / \mathrm{m}$ 程度で大きな差は見られなかったが, $800 \mathrm{~K}$ 近傍では $x=0$ から 0.02 にかけて絶対值が急激に増加 した後， $x \geq 0.02$ の試料ではほぼ $4-5 \times 10^{4} \mathrm{~S} / \mathrm{m}$ と飽和する傾 向がみられた。 $\sigma$ の $x$ 依存性が $S$ の場合と異なるのは, $S$ が 主にキャリア密度のみに依存するのに対し， $\sigma$ はキャリア密 度に加えて, 試料の微細組織に依存する移動度にも影響する からであろう。上述のように V 置換試料では, $x$ の増加とと 
もにモノシリサイド相の晶出が抑制されることがわかってお り，その結果移動度が上昇したものと推察される.

Fig. 4 (a) および (b) から算出される出力因子は $x=0.02$ の 試料で最大となり， $710 \mathrm{~K}$ において $1.86 \mathrm{~mW} / \mathrm{K}^{2} \mathrm{~m}$ と無置換試 料が同温度で示す $1.45 \mathrm{~mW} / \mathrm{K}^{2} \mathrm{~m}$ より約 $30 \%$ 向上することが 明らかになった。なお， $x=0.02$ 試料を $1200^{\circ} \mathrm{C}$ から $1100^{\circ} \mathrm{C}$ まで $1 \mathrm{~K} / \mathrm{h}$ の冷却速度で凝固させた「徐冷試料」はほぼ単結 晶と見なせるほどバルク試料内部の結晶方位が揃っており,

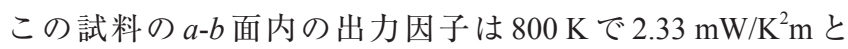
$\mathrm{HMS}$ 系最高の出力因子を示すことがわかっている ${ }^{19)}$. V の 僅かな置換は，モノシリサイド相の晶出抑制とホールドープ の両方の効果があるので, 実用的観点からも有望視されてい る. 熱伝導率は無置換試料と大きな差はなく, 組成によらず ほぼ $\kappa=3-4 \mathrm{~W} / \mathrm{K}^{2} \mathrm{~m}$ であったことから, 無次元性能指数 $Z T$ (= $P T / \kappa)$ は無置換試料の 0.2-0.3 程度から最大で $0.6(800 \mathrm{~K})$ 程度までほぼ 2 倍程度上昇することが確認された。

\section{HMS の熱膨張}

素子材料の熱膨張に関する知見は, 発電モジュールを形成 する際に極めて重要なデー夕となる，著者らは，高温X線 回折実験により種々の温度で HMS の回折デー夕を測定し, それらを Rietveld解析して格子定数の温度変化を評価した。 Fig. 5 (a)-(d)に $\mathrm{MnSi}_{1.7387(1)}$ 組成試料の格子定数の温度変化 (昇温時) を示す ${ }^{22}$. 解析には $(3+1)$ 次元の超空間群 $I 4_{1} /$ $\operatorname{amd}(00 \gamma) 00 s s$ を用いた。 この超空間群を用いることにより， $c_{\mathrm{Mn}}$ および $c_{\mathrm{Si}}$ 軸長の温度变化を独立して解析できる. Fig. 5 (a) および (b) から， $a$ 軸長および $c_{\mathrm{Mn}}$ 軸長は測定温度域で温 度とともに線形に増加する（一般的な熱澎張）ことが確認さ れた。一方, Fig. 5 (c) に示す $c_{\mathrm{Si}}$ 軸長は室温から $770 \mathrm{~K}$ 近傍
までは温度に対して直線的 $\left(2.504(1)+2.7(1) \times 10^{-5} T\right.$, 括弧 内の数字は最終桁の標準偏差) に増加するものの, $770 \mathrm{~K}$ 以 上では増加の割合（直線の傾き）が2.460(1) + 8.4(1) × $10^{-5} T$ と 3 倍に急増することが明らかになった。このことは, HMS の組成が温度変化することを示しており，実際 Fig. 5 (d) に 示すように室温から $770 \mathrm{~K}$ までは $\gamma=1.7387(1)$ と一定である のに対し，それ以上の温度では $\gamma$ が直線的に減少することが 明らかになった。 $1100 \mathrm{~K}$ 以上の測定は試料の酸化のためで きなかったが, $\gamma$ がこのまま直線的に減少すると, 融解する $1420 \mathrm{~K}$ では $\gamma \sim 1.72$ 程度になることが予想される，逆に融液か ら凝固する場合を考えると, 仮に液相から初晶として $\mathrm{MnSi}_{1.72}$ 近傍組成の HMS が凝固するとすれば，温度降下とともに組 成が $\gamma$ リッ側に徐々にシフトしていき，低温では Si が不 足するので一部がモノシリサイドに分解することも理に適う. こう考えると, 液相から固化させたHMSには常にモノシリ サイドが生成し，しかも HMS の $c$ 軸にほぼ垂直に晶出する ことも頡ける. 3 章で, $\gamma \sim 1.72$ 近傍の組成がモノシリサイド 相の抑制に効果があると断定したのは，この事実に由来する.

格子定数の温度変化から算出された線膨張率は $a$ 軸および $c_{\mathrm{Mn}}$ 軸に対してそれぞれ，11.95(2) × $10^{-6} \mathrm{~K}^{-1}$ および 12.60(2) $\times$ $10^{-6} \mathrm{~K}^{-1}$ と, 異方性の強い構造の割にはほぼ等方的な值で あった ${ }^{22)}$.これらの值は $\mathrm{Ti}$ 等の金属の值と同程度であり,

普通の金属が電極として使用可能なことを示している． $c_{\mathrm{Si}}$ 軸の線膨張率も $773 \mathrm{~K}$ 以下では $10.71(5) \times 10^{-6} \mathrm{~K}^{-1}$ と他の軸の それとほぼ同程度であったが， $773 \mathrm{~K}$ 以上では 32.81(4) $\times 10^{-6}$ $\mathrm{K}^{-1}$ と 3 倍近くになった. これらのことから, HMS はその熱 電性能が最高になる $800 \mathrm{~K}$ 付近で, 2 種類の構造単位が $c$ 軸 方向に異なる線脵張率を示しながら組成が変化する特徵（欠 陥）を内在していることがわかる.

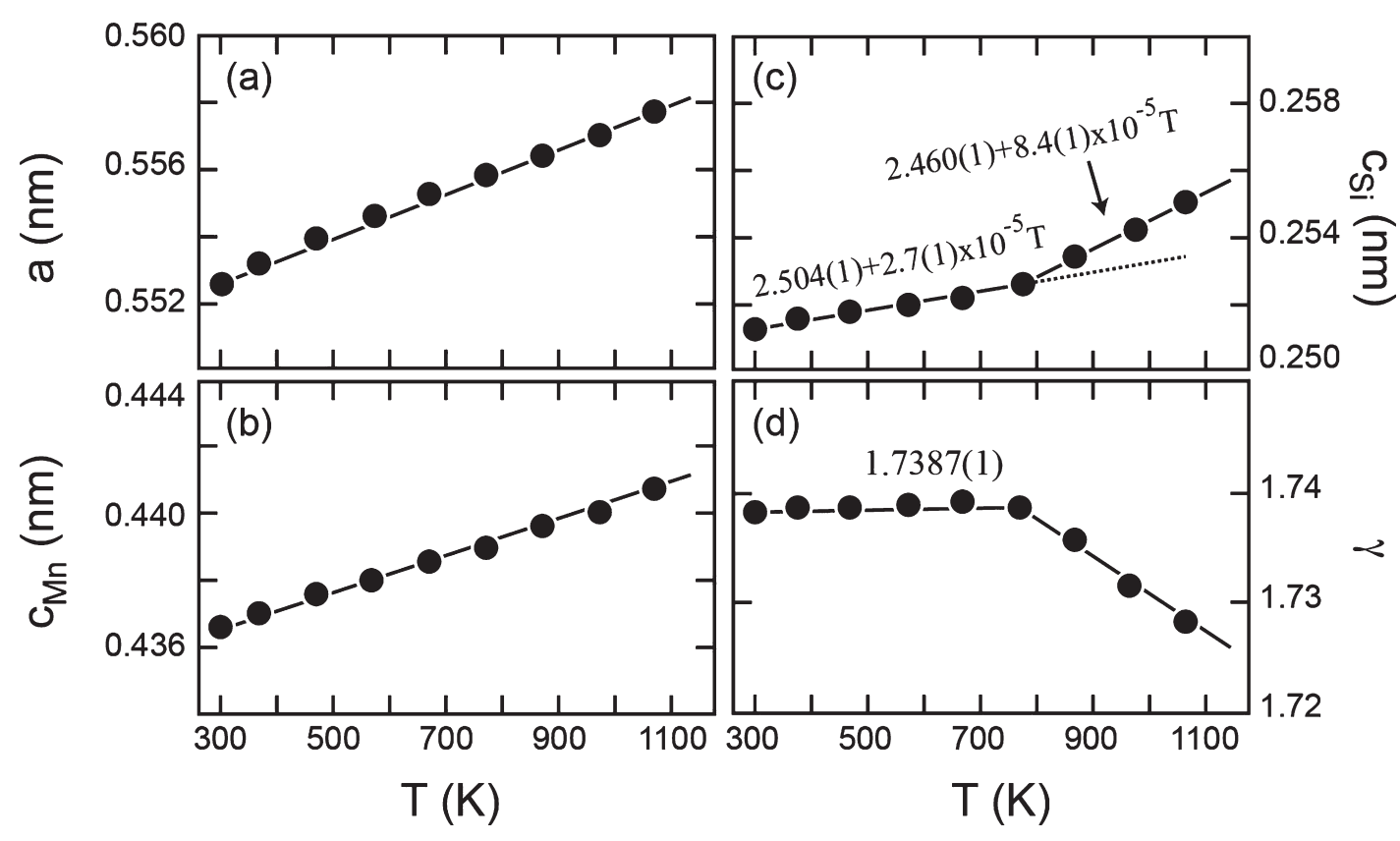

Fig. 5 Temperature evolution of the lattice parameters $a(\mathrm{a}), c_{\mathrm{Mn}}(\mathrm{b}), c_{\mathrm{Si}}(\mathrm{c})$ and $\gamma(\mathrm{d})$, of the $\mathrm{MnSi}_{1.7387(1)}$ sample ${ }^{22)}$. Reprinted from J. Alloys Compd., Vol. 616, Y. Kikuchi, T. Nakajo, K. Hayashi, Y. Miyazaki, High temperature X-ray diffraction study on incommensurate composite crystal MnSi ${ }_{\gamma}$ - (3+1)-dimensional superspace approach, p. 263-267, Copyright (2014), with permission from Elsevier. 


$$
7 \text { 結 言 }
$$

HMS の克服すべき課題と, その解決に向けた著者らの最 近の研究を紹介した。これまでの視点とは異なる, 結晶構造 に関連する特徴に着目することにより，ある程度の素子性能 の向上を図ることはできたが，実際のモジュール応用を見据 えた場合, 使用想定温度域で HMS の異常な熱膨張およびそ れに付随する組成変化を抑制する必要がある。その鍵はとな るのは，無置換試料のそれとはやや離れた $\gamma$ の值をもつ合金 であると著者らは考えている。

\section{文献}

1) V. K. Zaitsev: CRC Handbook of Thermoelectrics, ed. D. M. Rowe, New York, CRC Press (1995) chap. 25.

2) M. I. Fedorov, V. K. Zaitsev: Thermoelectrics Handbook Macro to Nano, ed. D. M. Rowe, Boca Raton, CRC Press (2006) chap. 31.

3) Y. Miyazaki, Y. Kikuchi: Thermoelectric Nanomaterials, Springer Series in Materials Science, eds. K. Koumoto and T. Mori, Heidelberg, Springer (2013) chap. 7.

4) Y. Miyazaki: J. Japan Inst. Met. Mater., 79 (2015) 530-537.

5) Y. Miyazaki: Materia Japan, 55 (2016) 307-310.

6) U. Gottlieb, A. Sulpice, B. Lambert-Andron, O. Laborde: J. Alloys Compd., 361 (2003) 13-18.

7) O. Schwomma, A. Preisinger, H. Nowotny, A. Wittmann: Monatsh. Chem., 95 (1964) 1527-1537.

8) G. Flieher, H. Völlenkle, H. Nowotny: Monatsh. Chem., 98 (1967) 2173-2179.

9) G. Zwilling, H. Nowotny: Monatsh. Chem., 104 (1973) $668-$ 675.

10) Y. Miyazaki, D. Igarashi, K. Hayashi, T. Kajitani, K. Yubuta: Phys. Rev. B, 78 (2008) 214104-1-214104-8.
11) H. Nowotny: The Chemistry of Extended Defects in NonMetallic Solids, eds. L. Eyring and M. O'Keeffe, North Holland, Amsterdam, (1970) 223-237.

12) Y. Miyazaki: Neutron Diffraction, ed. I. Khidirov, Intech Open Access Book, Rijeka, (2011) chap. 11.

13) D. B. Migas, V. L. Shaposhnikov, A. B. Filonov, V. E. Borisenko, N. N. Dorozhkin: Phys. Rev. B, 77 (2008) $075205-$ 1-075205-9.

14) R. DeRidder, G. van Tendeloo, S. Amelinckx: Phys. Stat. Sol. (a), 33 (1976) 383-393.

15) H. Q. Ye, S. Amelinckx: J. Solid State Chem., 33 (1976) $383-$ 393.

16) H. Okamoto: Binary Alloy Phase Diagrams vol. 3, ASM Handbook, ed. H. Baker, The Matrials Information Society, (1999) 2-289.

17) T. Kojima, I. Nishida, T. Sakata: J. Cryst. Growth, 47 (1979) 589-592.

18) I. Aoyama, M. I. Fedorov, V. A. Zaitsev, F. Y. Solomkin, I. S. Eremin, A. Y. Samunin, M. Mukoujima, S. Sano, T. Tsuji: Jpn. J. Appl. Phys., 44, (2005) 8562-8570.

19) Y. Miyazaki, H. Hamada, K. Hayashi, K. Yubuta, J. Electr. Mater., (2017) in press.

20) Agne Periodic Table, eds. S. Tanuma et al., AGNE Gijutsu Center, (2007).

21) Y. Miyazaki, Y. Saito, K. Hayashi, K. Yubuta, T. Kajitani: Jpn. J. Appl. Phys., 50 (2011) 035804-1-035804-5.

22) Y. Kikuchi, T. Nakajo, K. Hayashi, Y. Miyazaki: J. Alloys Compd., 616 (2014) 263-267. 